\title{
Comparative study of permanent magnet- synchronous and permanent magnet-flux switching machines for high torque to inertia applications
}

\author{
A. Al-Timimy ${ }^{*}$, P. Giangrande*, M. Degano*+, M. Galea*, C. Gerada ${ }^{*+}$
}

\begin{abstract}
This paper investigates the capability of both permanent magnet synchronous machine (PMSM) and permanent magnet flux switching (PMFS) machine to provide high torque to inertia ratio for applications with demanding response in terms of acceleration and fast dynamic. The PMSM has higher torque density and efficiency among different electrical machines. However, the presence of the permanent magnets can increase the rotor inertia. Thanks to its passive salient-pole rotor, PMFS machine is a suitable solution for those applications requiring lower inertia. This paper provides a comparative analysis between the PMSM and PMFS machines considering the torque to inertia ratio, the challenges of a flooded air gap and dimensional constraints. The electromagnetic performances of both machines have been evaluated by means of finite element method and a detailed sensitivity analysis is carried out for stator and rotor geometry.
\end{abstract}

Index Terms--Flux switching machine, permanent magnet machine, finite element method, high torque to inertia ratio.

\section{INTRODUCTION}

$\mathrm{P}$ ERMANENT magnet synchronous machines (PMSMs) have been widely used in high performance drives thanks to their high power density, high efficiency and compactness [1]. However, the presence of the permanent magnets on the rotor can lead to higher moment of inertia, which might set a challenge in applications targeting fast dynamic response. In fact, for critical applications where fast accelerations are often required, it's preferred to have lower inertia [2]. This goal might be achieved by adopting an electrical machine with all the excitation sources, such as permanent magnets and armature windings, placed on the stator. With the aim of addressing the above mentioned issues, a permanent magnet flux switching (PMFS) machine has been investigated in this paper. PMFS machine, which combines the advantages of PM synchronous and switched reluctance machines, has received great attention in recent years thanks to their high power density, torque capability, wide constant power speed range and robust rotor construction [1], [2]. Furthermore, their operational characteristics are similar to those of PMSMs.

Several comparative studies between PMSM and PMFS machine are proposed in literature. In [3], the potential advantages of PMFS machine over the PMSM, for electric

A. Al-Timimy ${ }^{*}$, P. Giangrande*, M. Degano ${ }^{*+}$, M. Galea ${ }^{*}$ and C. Gerada ${ }^{*+}$ are with the Power Electronics, Machines drives and Control Group. *PEMC Group, the University of Nottingham, Nottingham, UK. +PEMC Group, the University of Nottingham Ningbo China, Ningbo, China.

A. Al-Timimy (e-mail: Ahmed.Al-Timimy@nottingham.ac.uk) vehicle traction applications are investigated. The electromagnetic performance of PMFS machines with respect to PMSM have been compared in [4]. The study highlights a slightly better torque capability (for the same copper losses) of the PMFS machine despite of their higher cogging torque. In [5], high power density PMFS machine has been designed and its performance has been compared to IPM machine for the same overall dimensions and operation conditions. 3-D end effects and rotor eccentricity are also evaluated by means of finite element analysis in [5]. The fault tolerant capability of both PMSM and PMFS machines have been presented in [1] and [6] considering open- and short-circuit faults.

A three-phase 12 slots 10 poles PMFS machine for highperformance servo applications such as spindle cutter has been considered in [2]. The PMFS machine has been optimized for lower rotor inertia, maximum torque and overloading capability. Particular attention has been paid on the effect of different rotor parameters in order to minimize the rotor inertia and cogging torque. The presented results shows a good dynamic response with smooth torque profile. However, in [2] the effect of ribs on rotor inertia and windage losses is not taken into account.

In the mentioned papers, the comparison between PMFS and PMSM machines has been carried out in terms of torque density, reliability and fault tolerant. Nevertheless, the torque to inertia ratio and its influence on machine design have not been compared in literature. In this work, the authors are presenting a detailed analysis of a high power density PMFS machine and compares its performance in terms of torque to inertia ratio to $9 \mathrm{~s} / 8 \mathrm{p}$ PMSM with the same volume constraint.

\section{DESIGN REQUIREMENTS AND CONSTRAINTS}

The required specifications for both the reference PMSM and the designed PMFS machine are shown in Table 1. A maximum continues torque has to be delivered within a speed range from 0 to $8700 \mathrm{rpm}$. Beyond the base speed of $8700 \mathrm{rpm}$, flux weakening is allowed until the maximum speed of $19000 \mathrm{rpm}$. The machine design needs to fulfil several constraints, such as the geometrical dimensions due to the restrained available space and the active parts weight. The machine is designed to drive a flooded pump and a low moment of inertia is required, in order to provide higher and fast acceleration of the machine shaft. 
TABLE 1

DESIGN SPECIFICATIONS

\begin{tabular}{|l|c|c|}
\hline Parameters & Value & Units \\
\hline Dc link voltage & 210 & $\mathrm{Vdc}$ \\
\hline Max. current & $\leqq 85$ & $\mathrm{~A}$ \\
\hline Torque @ $8700 \mathrm{rpm}$ & 10.5 & $\mathrm{Nm}$ \\
\hline Torque @19000 rpm & 5 & $\mathrm{Nm}$ \\
\hline THD of BEMF & $\leqq 5$ & $\%$ \\
\hline Moment of inertia & $\leqq 1 \times 10^{-4}$ & $\mathrm{~kg} \cdot \mathrm{m}^{2}$ \\
\hline Weight & $\leqq 2.5$ & $\mathrm{~kg}$ \\
\hline Stack length & $\leqq 85$ & $\mathrm{~mm}$ \\
\hline Axial cross section & $\leqq 70 \times 70$ & $\mathrm{~mm}$ \\
\hline Cooling system & Flooded & - \\
\hline Max. temperature & 210 & ${ }^{\circ} \mathrm{C}$ \\
\hline Ambient temperature & 90 & ${ }^{\circ} \mathrm{C}$ \\
\hline Laminations & VacoFlux 48 & - \\
\hline Magnet grade & $\begin{array}{c}\text { RECOMA } 33 \mathrm{E} \\
(\text { Sm2Co17) }\end{array}$ & \multicolumn{1}{|c|}{} \\
\hline
\end{tabular}

\section{REFERENCE MACHINES DESIGN}

Based on the design requirements and constraints listed in Table 1, PMSM with 8 pole and 9 slot has been previously investigated, designed and optimized in order to meet the required specifications. More details with respect to the design approach and the optimization procedure of the PMSM can be found in [7] and [8] while in [9], the thermal management has been analyzed in detailed. During the PMSM design, the main challenge was to meet the required specifications, especially the one regarding the moment of inertia.

The reason was identified because of the permanent magnet presence on the rotor, made by materials with higher mass density compared to the rotor ones (17-4 PH Stainless Steel with mass density $7820 \mathrm{~kg} / \mathrm{m}^{3}$ ). In addition, Samarium Cobalt material for the permanent magnet was selected because of its lower temperature coefficient (highest stability), which presents a higher mass density $8300 \mathrm{~kg} / \mathrm{m}^{3}$ compared to $7500 \mathrm{~kg} / \mathrm{m}^{3}$ for Neodymium Iron Boron magnet. The distribution of rotor inertia is shown in Fig. 1, where the main contribution to the moment of inertia is given by the magnets, since the inertia is proportional to rotor the radius squared. In order to keep low the moment of inertia, a hollow shaft solution was adopted during the PMSM design.

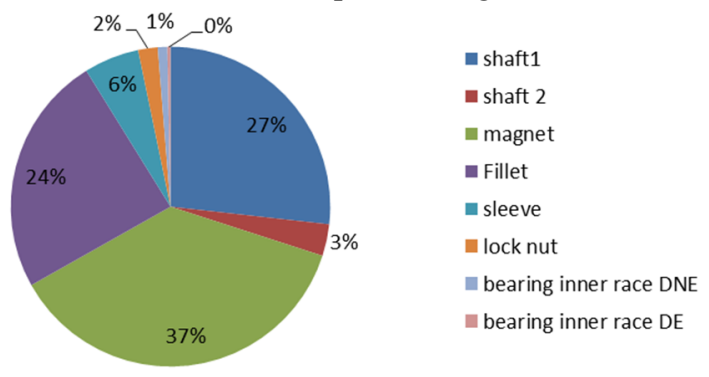

Fig. 1. Inertia distribution of rotor for $8 \mathrm{p} / 9 \mathrm{~s}$ PMSM

The inertia requirement is in contrast to the output torque maximization. On one hand, the torque can be increased by increasing the rotor diameter, but this will lead to high inertia due to the bigger rotor size. On the other hand, reducing the rotor diameter will have an impact in reducing the output torque. Therefore, a trade-off between output torque and moment of inertia has been achieved, as described in [7]. In order to summarize the $8 \mathrm{p} / 9 \mathrm{~s}$ PMSM final design, Fig. 2 shows its cross-sectional area while Table 2 reports the geometrical dimensions along with the performance results in both the required operating conditions (constant torque and flux weakening).

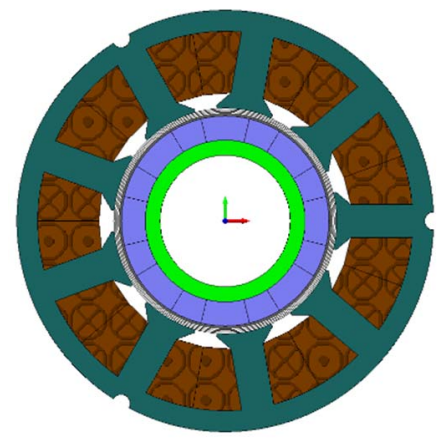

Fig. 2. Cross-section of 9s/8p PMSM

From Table 2 it is clear that the designed machine satisfies the requirements in terms of geometrical dimensions, weight and moment of inertia.

TABLE 2

MACHINE GEOMETRICAL DIMENSIONS AND PERFORMANCE INDICATIORS

\begin{tabular}{|c|c|c|}
\hline Geometrical dimensions & \multicolumn{2}{|c|}{ Values } \\
\hline Stack Length & \multicolumn{2}{|c|}{$80 \mathrm{~mm}$} \\
\hline Stator outer diameter & \multicolumn{2}{|c|}{$70 \mathrm{~mm}$} \\
\hline Stator inner diameter & \multicolumn{2}{|c|}{$37.45 \mathrm{~mm}$} \\
\hline Split ratio & \multicolumn{2}{|c|}{0.535} \\
\hline Air-gap thickness (g) & \multicolumn{2}{|c|}{$0.9 \mathrm{~mm}$} \\
\hline Fill factor (FF) & \multicolumn{2}{|c|}{0.36} \\
\hline Performance Indicators & $\begin{array}{c}10.5 \text { Nm@ } \\
8700 \text { rpm }\end{array}$ & $\begin{array}{c}5 \mathrm{Nm} @ \\
19000 \mathrm{rpm}\end{array}$ \\
\hline Current density $\mathrm{J}\left(\mathrm{A} / \mathrm{mm}^{2}\right)$ & \multicolumn{2}{|c|}{27.2 RMS } \\
\hline Efficiency (\%) & 91.2 & 86.5 \\
\hline Torque ripple (\%) & 0.5 & 0.8 \\
\hline Back-EMF THD (\%) & 3.13 & 3.14 \\
\hline Moment of inertia $\left(\mathrm{kg} \cdot \mathrm{m}^{2}\right)$ & \multicolumn{2}{|c|}{ 8. $e^{-5}$} \\
\hline
\end{tabular}

\section{Design OF PMFS MACHINE}

The challenge of meeting the inertia requirements, due to the high mass density of the permanent magnets, in PMSM have been highlighted in the previous sections. In order to investigate a competitive solution to this aspects, a PMFS machine, thanks to the robust rotor construction and lower moment of inertia, has been analyzed and compared to the designed 9s/8p PMSM. Different stator slot - rotor pole combinations and possible winding configurations, for the PMFS machine, have been investigated in detailed in [10], [11] and [12]. While the effect of different design parameters on the slot-pole combination has been addressed in [13], [14]. In terms of stator, a 6-slots stator has been selected in order to allow the placement of the permanent magnets on the stator. Since the fundamental frequency of the PMFS machine is proportional to the number of the rotor poles and 
not to the pole pairs as in PMSM, rotors with 4, 5, 7 and 8 poles have been identified to be suitable for the considered application. Among the possible slot-pole combinations, the $6 s / 4 p$ and $6 s / 8 p$ have been eliminated from the study due to the unbalanced back-emf and the distorted non-sinusoidal waveform of the flux linkage [12]. Due to the asymmetry of the rotor, both $6 \mathrm{~s} / 5 \mathrm{p}$ and $6 \mathrm{~s} / 7 \mathrm{p}$ FSPM machines are showing unbalanced magnetic forces acting on the rotor [15]. In spite of this, the $6 \mathrm{~s} / 7 \mathrm{p}$ PMFS machine has been selected, due to the higher torque density. According to [14], the initial design of PMFS machine has been initialized assuming the following:

$$
\begin{aligned}
& \text { 1) } T_{w}=M_{t}=S_{b i}=R_{b i}=S_{o}=R_{p h}=R_{p w}=S S / 4 \\
& \text { 2) } S r=D_{s i} / D_{s o}=0.5
\end{aligned}
$$

Where, $T_{w}$ is the tooth width, $M_{t}$ is the magnet thickness, $S_{b i}$ is the stator back iron, $R_{b i}$ is the rotor back iron, $S_{o}$ is the slot opening, $R_{p h}$ is the rotor pole height, $R_{p w}$ is the rotor pole width, $S S$ is the stator tooth pitch and $S r$ is the split ratio, as shown in Fig. 3.
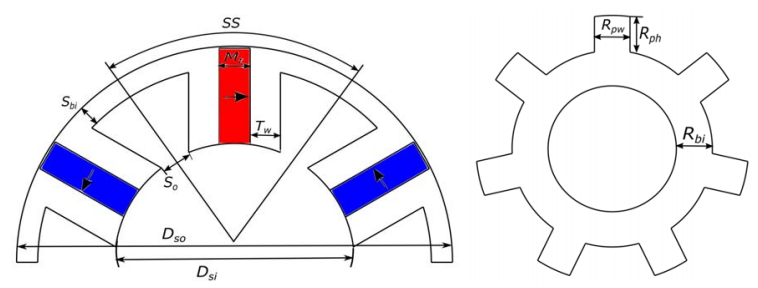

Fig. 3. Cross-section of the $6 \mathrm{~s} / 7 \mathrm{p}$ PMFS

For a fair design comparison, both machines $(9 \mathrm{~s} / 8 \mathrm{p}$ PMSM and 6s/7p PMFS) have a fixed envelope size. Fig. 4-a shows the initial $6 \mathrm{~s} / 7 \mathrm{p}$ PMFS machine design. It is clear that the PMFS machine has a higher magnetic saturation, especially in the stator teeth edges, permanent magnet and rotor pole, which could reach up to $2.9 \mathrm{~T}$ as shown in Fig. 4b.

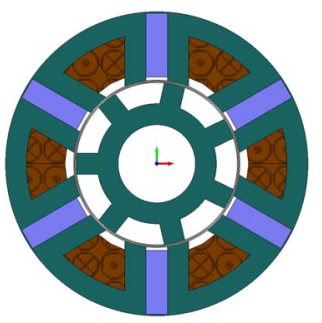

(a)

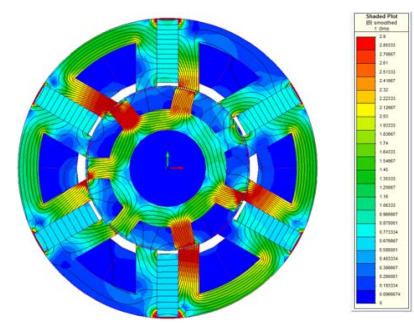

(b)
Fig. 4. 6s/7p PMFS machine (a) 2D cross-section (b) Flux density map

\section{DETAILED SENSITIVITY ANALYSIS OF PMFS MACHINE}

The preliminary machine design shown in Fig. 4 has been analyzed considering different geometrical parameters in order to investigate the torque and rotor inertia requirements. The sensitivity analysis is considering the copper losses, of $6 s / 7 p$ PMFS machine, to be fixed to the same value of the original 9s/8p PMSM. The selected variable parameters are: split ratio, stator tooth width, stator magnet thickness, stator back iron thickness, rotor tooth width, rotor tooth height and rotor back iron thickness.
Split ratio $(\mathrm{Sr})$ is one of the most important design parameters to maximize the output torque. Fig. 5 shows the variation of the output torque and rotor moment of inertia with the split ratio for a fixed amount of copper losses (630 W). From the graph it can be noted that a split ratio of 0.55 provides maximum torque $(10.72 \mathrm{Nm})$ and acceptable rotor moment of inertia around 5.94. $e^{-5} \mathrm{~kg} \cdot \mathrm{m}^{2}$.

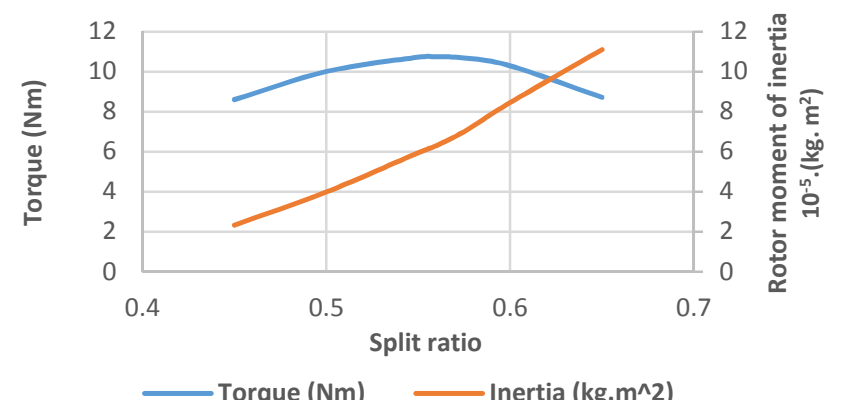

Fig. 5. Influence of the split ratio on average torque and rotor moment of inertia

In order to optimize the stator tooth width, the magnet thickness has been kept constant and equal to $1 / 4$ of the stator tooth pitch and the stator tooth width is varied for the fixed value of copper losses $(630 \mathrm{~W})$. Fig. 6 shows the influence of stator tooth width on both average torque and torque ripple, presenting an optimal relative value of $1 \mathrm{pu}$, which equals to $1 / 4$ of the stator tooth pitch.

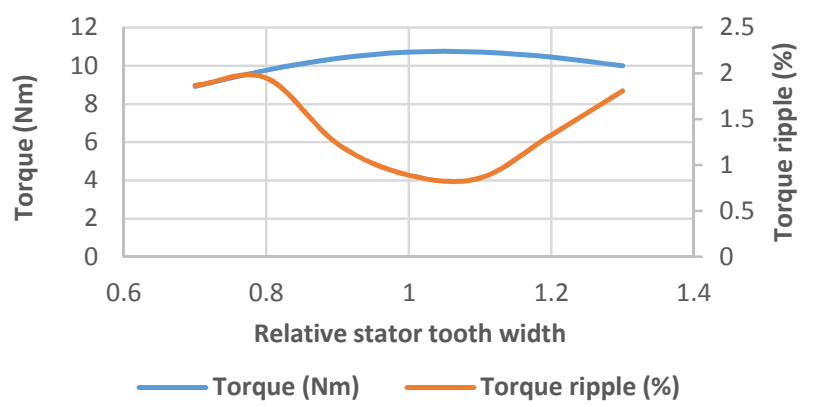

Fig. 6. Influence of the relative stator tooth span on average torque and torque ripple

Initially, the magnet thickness which is set equal to $1 / 4$ of the stator tooth pitch has been optimized in order to achieve the required torque with lower amount of magnet material. Fig. 7 shows the effect on the magnet thickness on the average torque and torque ripple, while the tooth width is fixed to the selected optimal value. A relative magnet thickness of 1 pu gives a good compromise between the torque and the torque ripple.

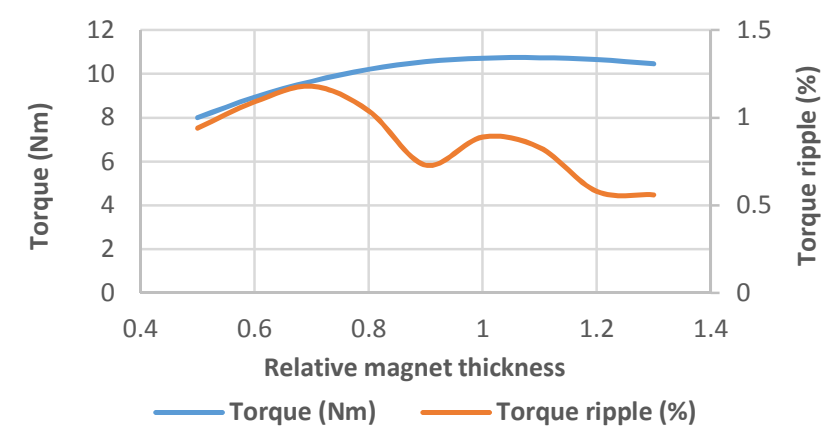

Fig. 7. Influence of the relative magnet thickness span on average torque and torque ripple 
The stator back iron has been selected in order to reach the knee point of the $\mathrm{BH}$ curve for the CoFe material. Fig. 8 shows the trend of both average torque and torque ripple as function of the stator back iron thickness.

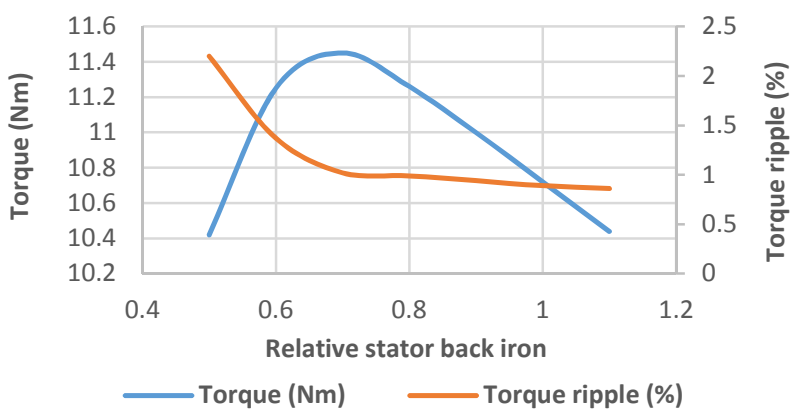

Fig. 8. Influence of the relative stator back iron span on average torque and torque ripple

Fig. 9 reports the variation of the average torque and rotor moment of inertia with the rotor pole span. It is clear that by increasing the rotor pole span up to $1.1 \mathrm{pu}$, a higher torque could be achieved because of the higher flux linkage.

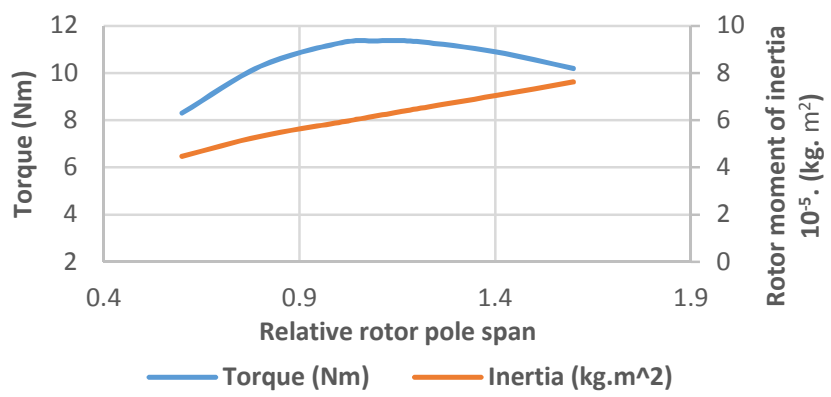

Fig. 9. Influence of the relative rotor pole span on average torque and rotor movement of inertia

It has been noted that increasing the rotor pole span above the $1.1 \mathrm{pu}$ value, the flux leakage, in the proximity of the slot opening and the inner radius of the magnet, is increased. As a consequence, the phase flux linkage and average torque are decreased. Considering Fig. 10, the relative rotor pole span of 1.1 is selected to obtain the maximum torque. Furthermore, the average torque is improved by increasing the rotor pole height due to the rotor saliency. Maximum torque is achieved when the rotor pole height is 1.4 times the stator tooth pitch as shown in Fig. 10.

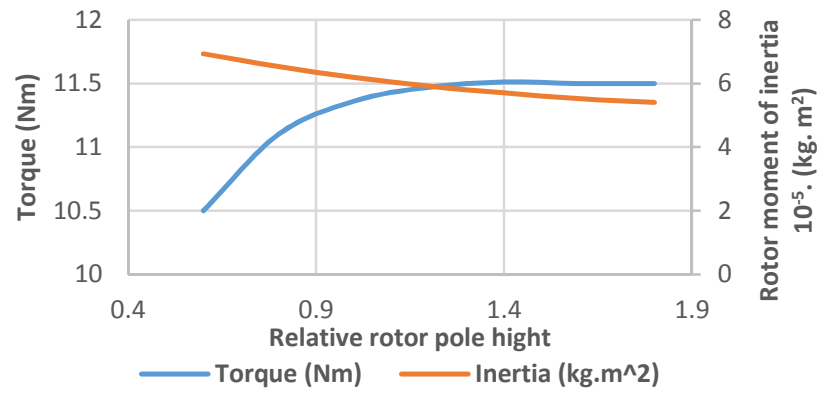

Fig. 10. Influence of the relative rotor pole height on average torque and rotor movement of inertia

The impact of the rotor back iron thickness on the average torque and rotor moment of inertia has been investigated and the obtained results are reported in Fig. 11. According to this figure, the minimum rotor back iron thickness, which provides the required torque and lower inertia is equal to $0.75 \mathrm{pu}$.

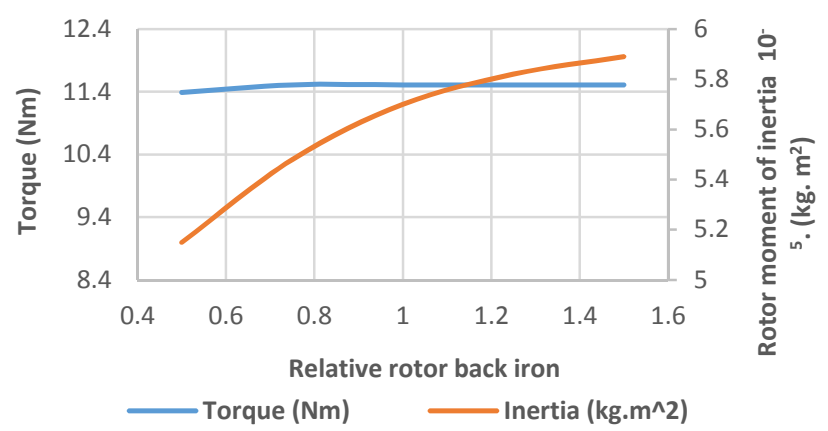

Fig. 11. Influence of the relative rotor back iron on average torque and rotor movement of inertia

At this stage, the $6 \mathrm{~s} / 7 \mathrm{p}$ PMFS machine with salient poles on the rotor surface has been analyzed in detail. However, due to the cooling system requirements (i.e. the air gap is flooded in oil) the windage losses for this machine are extremely high, because of the salient rotor geometry, especially at higher speeds during the field weakening operating conditions. Therefore, magnetic ribs with $0.2 \mathrm{~mm}$ thickness has been added between two adjacent salient poles, as shown in Fig. 12. The introduction of the magnetic ribs offers a smooth cylindrical rotor surface, which presents lower windage losses [16], without compromising the rotor inertia. Fig. 13 shows the windage losses variation of the $6 \mathrm{~s} / 7 \mathrm{p}$ PMFS machine using both smooth cylindrical rotor surface and salient pole rotor surface. At the maximum operational speed of $19000 \mathrm{rpm}$, the windage losses of the salient pole rotor are $3062.2 \mathrm{~W}$, while for the cylindrical rotor surface is $572.54 \mathrm{~W}$ (about $80 \%$ lower at same speed).

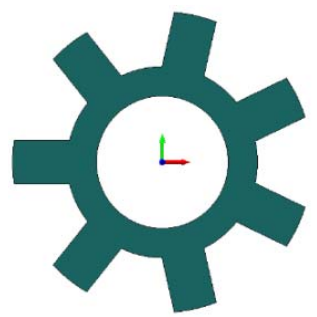

(a)

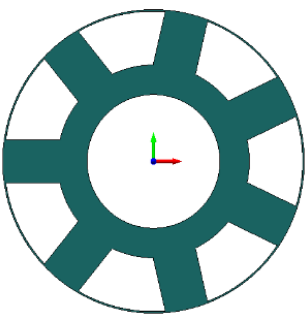

(b)
Fig. 12. 6s/7p PMFS machine with different rotor geometry (a) Rotor with salient poles (b) Rotor with magnetic ribs

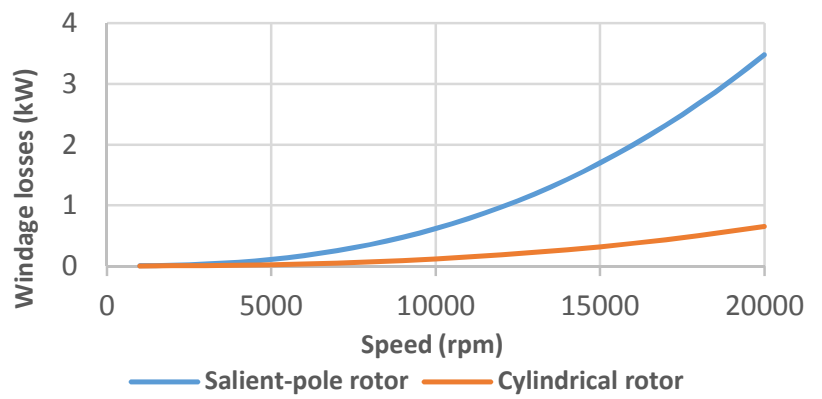

Fig. 13. Windage losses calculation of salient pole rotor and cylindrical rotor 
Nevertheless, the electromagnetic torque drops by $12.33 \%$ (from $11.51 \mathrm{Nm}$ to $10.09 \mathrm{Nm}$ ), due to the leakage flux in the magnetic ribs, as shown in Fig. 14. Considering the mechanical aspect, a solid shaft is required to hold the rotor laminations of the PMFS machine.

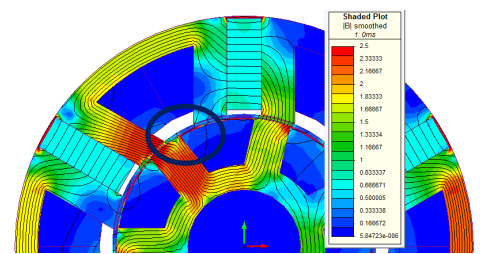

(a)

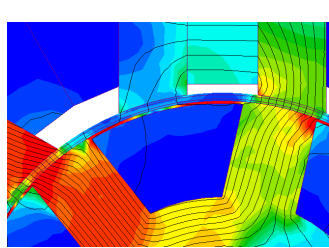

(b)
Fig. 14. Flux density map of $6 \mathrm{~s} / 7 \mathrm{p}$ PMFS machine with modified rotor (a) Flux density map (b) Enlarged section of rotor with magnet ribs

Indeed, it's difficult to have a hollow rotor shaft, since the inner diameter of the rotor is small (around $16.4 \mathrm{~mm}$ ). Therefore, 316 Stainless Steel material with mass density of $8238 \mathrm{~kg} / \mathrm{m}^{3}$ has been chosen for the solid shaft. Including the solid shaft, the total moment of inertia is equal to $6.3 e^{-5} \mathrm{~kg} \cdot \mathrm{m}^{2}$ and the torque to inertia ratio is 1.6 . $e^{5} \mathrm{Nm} / \mathrm{kg} \cdot \mathrm{m}^{2}$. For the same stack length of $80 \mathrm{~mm}$ and stator outer diameter $70 \mathrm{~mm}$, the PMFS machine has $21.25 \%$ moment of inertia lower than the PMSM machine.

\section{PERFormance COMPARISON RESUlts}

The electromagnetic performance of the two PMFS machine (with and without magnetic ribs) have been analyzed and the obtained results have been compared to the PMSM ones. The analysis has been performed at rated speed of $8700 \mathrm{rpm}$ by means of 2D finite element simulations. The PMFS machine with magnetic ribs is a suitable solution for flooded air gap solutions, while the PMFS with salient poles is a convenient option in case of natural-air cooling system. In this analysis the stator outer diameter and the stack length were fixed to $70 \mathrm{~mm}$ and $80 \mathrm{~mm}$ respectively, while the performance evaluated for different current densities. Fig. 15 shows the electromagnetic torque versus current densities. Increasing the armature current, the output torque will increase, but the torque value is limited to the magnetic saturation of the machine core. Using same magnetic material for the stator core, the PMFS machines reaches the saturation limit faster than the PMSM machine, especially at the edges of the stator teeth, rotor poles and ribs. For the same envelop size it is worthy to note that the PMSM has higher torque density compared to PMFS machines as shown in Fig. 16, due to the higher torque and lower total mass of the PMSM. In Fig. 17 instead the effect of the current densities on the torque to inertia ratio of the machines is reported. It is clear that the PMFS machine without magnetic ribs can provide higher acceleration values due to the combination of low moment of inertia and high torque. Conversely, the PMFS machine with magnetic ribs gives higher acceleration values compared to PMSM up to $30 \mathrm{~A} / \mathrm{mm}^{2}$. For current density values higher than $30 \mathrm{~A} / \mathrm{mm}^{2}$, the PMSM is performing with better dynamic, due the saturation of the magnetic ribs. Table 3 summaries the comparison between $6 \mathrm{~s} / 7 \mathrm{p}$ PMFS machines and the reference $9 \mathrm{~s} / 8 \mathrm{p}$ PMSM in terms of moment of inertia, torque to inertia ratio, torque density and total mass of the machine. Considering the results listed in Table 3, the PMFS machine with magnetic ribs provides better torque to inertia ratio $\left(1.66 \cdot \mathrm{e}^{5} \mathrm{Nm} / \mathrm{kg} \cdot \mathrm{m}^{2}\right)$ when both stack length and stator outer diameter are kept the same for the machines under comparison (Conventional case). In this condition, satisfactory dynamic performance can be achieved, even though the current density needs to be increased $\left(38.17 \mathrm{~A} / \mathrm{mm}^{2}\right)$ in order to meet the output torque requirement. Higher current density values will lead to higher copper losses, which will compromise the efficiency. Furthermore, the power module size might be increased as well as the cooling capability of the cooling system.

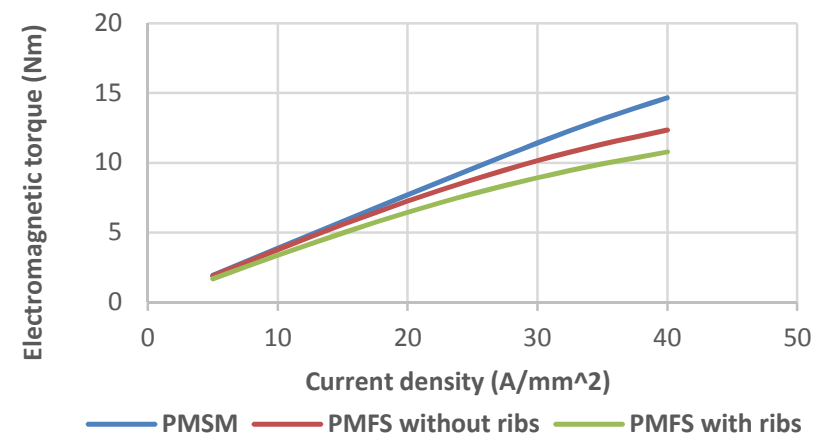

Fig.15. Electromagnetic torque versus current density

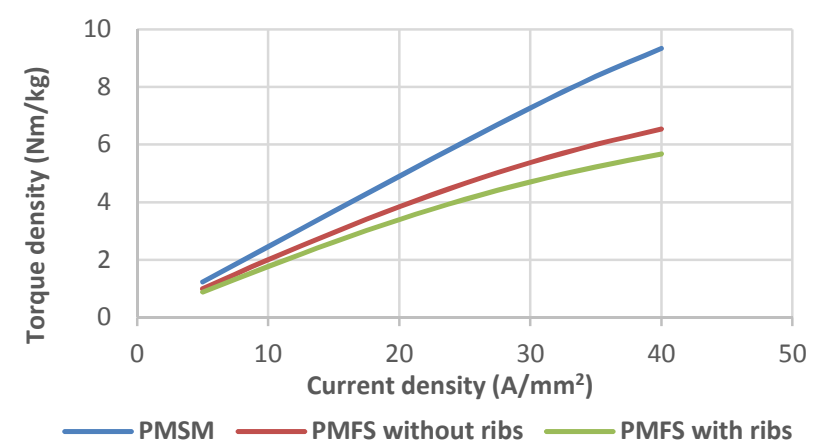

Fig.16. Torque density versus current density

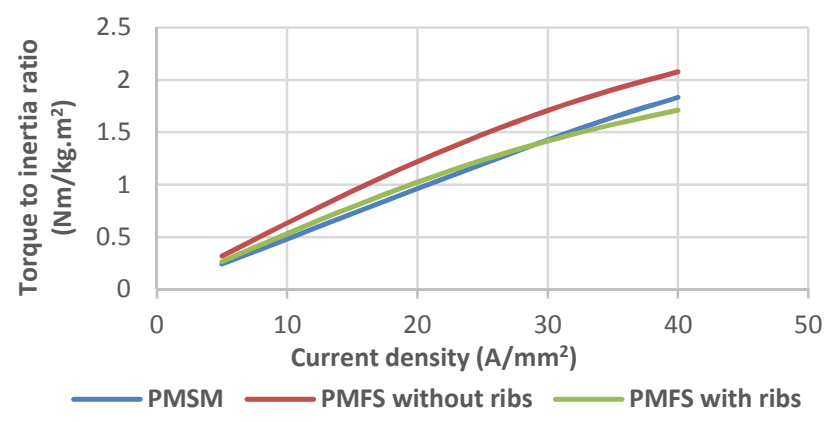

Fig.17 Torque to inertia ratio versus current density

The required torque can be also achieved by acting on the machine geometry (mainly stack length and stator outer diameter) by keeping constant the current density. Following this approach, the PMFS machines stack length was varied, while both stator outer diameter $(70 \mathrm{~mm})$ and current density $\left(27.2 \mathrm{~A} / \mathrm{mm}^{2}\right.$ ) were kept constant (case of changing the stack length in Table 3). Under these conditions, the stack length of the PMSF machine without magnetic ribs needs to be increased by the $10.56 \%$ (from $80 \mathrm{~mm}$ to $88.45 \mathrm{~mm}$ ), in 
order to develop an output torque of $10.5 \mathrm{Nm}$. Due to the magnetic saturation, the increase of axial length required by the PMFS machine with magnetic ribs is also higher. Indeed for this machine, $10.5 \mathrm{Nm}$ are provided when the stack length is increased from $80 \mathrm{~mm}$ to $98.94 \mathrm{~mm}$ (about 23.67\% more). The augment of stack length will affect torque to inertia ratio of the PMFS machines, although the moment of inertia values are still slightly lower compared to the one of the PMSM. The analysis was completed by varying the stator outer diameter of the PMFS machines (case of changing the stator outer diameter in Table 3), while both stack length $(80 \mathrm{~mm})$ and current density $\left(27.2 \mathrm{~A} / \mathrm{mm}^{2}\right)$ were kept constant. In this case, a reduction of the torque to inertia ratios is observed, for both PMFS machines (with and without ribs). Considering the PMSF machine with magnetic ribs, the torque to inertia ratio is decreased by $5.3 \%$ compared to the case when the stack length is changed, while a reduction of $2.5 \%$ is obtained for the PMSF machine without magnetic ribs. Such reduction is due to the inertia formulation, since it is proportional to the fourth power of the rotor radius.

TABLE 3

COMPARISION OF PMSM VS. PMFS

\begin{tabular}{|c|c|c|c|}
\hline & \multicolumn{2}{|c|}{$\begin{array}{l}\text { 6s/7p } \\
\text { PMFS }\end{array}$} & \multirow{2}{*}{$\begin{array}{c}\text { 9s/8p } \\
\text { PMSM }\end{array}$} \\
\hline & ribs & No ribs & \\
\hline & \multicolumn{3}{|c|}{ Conventional case } \\
\hline Average torque (Nm) & 10.5 & 10.5 & 10.5 \\
\hline Moment of inertia $\left(\mathrm{kg} \cdot \mathrm{m}^{2}\right)$ & $6.28 \cdot e^{-5}$ & $5.92 \cdot e^{-5}$ & $8 \cdot \mathrm{e}^{-5}$ \\
\hline Torque/Inertia ratio $\left(\mathrm{Nm} / \mathrm{kg} \cdot \mathrm{m}^{2}\right)$ & $1.66 \cdot \mathrm{e}^{5}$ & $1.76 \cdot \mathrm{e}^{5}$ & $1.31 \cdot \mathrm{e}^{5}$ \\
\hline Slot current density $\left(\mathrm{A} / \mathrm{mm}^{2}\right)$ & 38.17 & 31.5 & 27.2 \\
\hline Torque density (Nm/kg) & 5.52 & 5.96 & 6.68 \\
\hline \multirow[t]{2}{*}{ Mass (kg) } & 1.9 & 1.76 & 1.57 \\
\hline & \multicolumn{3}{|c|}{ Changing stack length } \\
\hline Average torque $(\mathrm{Nm})$ & 10.5 & 10.5 & 10.5 \\
\hline Moment of inertia $\left(\mathrm{kg} \cdot \mathrm{m}^{2}\right)$ & $7.96 \cdot e^{-5}$ & $6.59 \cdot e^{-5}$ & $8 \cdot e^{-5}$ \\
\hline Torque/Inertia ratio $\left(\mathrm{Nm} / \mathrm{kg} \cdot \mathrm{m}^{2}\right)$ & $1.32 \cdot \mathrm{e}^{5}$ & $1.58 \cdot \mathrm{e}^{5}$ & $1.31 \cdot \mathrm{e}^{5}$ \\
\hline Slot current density $\left(\mathrm{A} / \mathrm{mm}^{2}\right)$ & 27.2 & 27.2 & 27.2 \\
\hline Torque density (Nm/kg) & 4.7 & 5.41 & 6.68 \\
\hline \multirow[t]{2}{*}{ Mass (kg) } & 2.23 & 1.94 & 1.57 \\
\hline & \multicolumn{3}{|c|}{ Changing stator outer diameter } \\
\hline Average torque (Nm) & 10.5 & 10.5 & 10.5 \\
\hline Moment of inertia $\left(\mathrm{kg} \cdot \mathrm{m}^{2}\right)$ & $8.32 \cdot e^{-5}$ & $6.77 \cdot e^{-5}$ & $8 \cdot e^{-5}$ \\
\hline Torque/Inertia ratio $\left(\mathrm{Nm} / \mathrm{kg} \cdot \mathrm{m}^{2}\right)$ & $1.25 \cdot \mathrm{e}^{5}$ & $1.54 \cdot \mathrm{e}^{5}$ & $1.31 \cdot \mathrm{e}^{5}$ \\
\hline Slot current density $\left(\mathrm{A} / \mathrm{mm}^{2}\right)$ & 27.2 & 27.2 & 27.2 \\
\hline Torque density (Nm/kg) & 5.19 & 5.64 & 6.68 \\
\hline Mass (kg) & 2.02 & 1.86 & 1.57 \\
\hline
\end{tabular}

Furthermore, acting on the stator outer diameter, apart from reducing the torque to inertia ratio, it also benefits the machine mass, due to the constant current density. Indeed, acting on the stator outer diameter, the torque density of the PMFS machines increases by $10.4 \%$ (with magnetic ribs) and $4.2 \%$ (without magnetic ribs), compared to the case of increasing the stack length.

\section{CONCLUSION}

In this paper, two machine topologies namely PMSM and PMFS have been investigated and compared in terms of torque to inertia ratio (with effect on dynamic performance) and its influence on the machine design parameters. A detailed sensitivity analysis has been carried out for different geometrical variables of the PMFS and compared with the PMSM optimized reference machine. Additional analysis, focused on the adoption of magnetic ribs for the PMFS motor, has been carried out in order to investigate both effects on windage losses and torque to inertia. For the application under study, PMSF machine has lower torque density compared to the PMSM machine (for the same volume). Nevertheless, PMSF machine could provide faster accelerations, due to the lower rotor inertia. This work proposes an alternative machine design to the PMSM, using a PMFS machine with magnetic ribs. The latter, on one hand ensures better dynamic performances (lower torque to inertia ratio) in comparison to the PMSM previously designed and meets the moment of inertia constraint. On the other hand, in order to meet the torque requirements, the current density needs to be significantly increased $(\sim 40 \%)$, without changing the machine dimensions.

\section{REFERENCES}

[1] T. Raminosoa, and C. Gerada "A comparative study of permanent magnet-synchronous and permanent magnet-flux switching machines for fault tolerant drive systems." IEEE ECCE2010.

[2] E. Ilhan, T.L. Balyovski, J.J.H. Paulides and E.A. Lomonova, "Servo flux switching PM machines", ICEM 2014, Berlin, 2014, pp. 634-640.

[3] T. Yang, et al. "Comparison of flux-switching machines and permanent magnet synchronous machines in an in-wheel traction application", COMPEL-The international journal for computation and mathematics in electrical and electronic engineering (2012), 153-165.

[4] H. Wei, et al. "Comparison of electromagnetic performance of brushless motors having magnets in stator and rotor." Journal of Applied Physics 2008.

[5] H. Wei, G. Zhang, and M. Cheng. "Investigation and Design of a High-Power Flux-Switching Permanent Magnet Machine for Hybrid Electric Vehicles." IEEE Transactions on Magnetics (2015).

[6] T. Raminosoa, C. Gerada, and M. Galea. "Design considerations for a fault-tolerant flux-switching permanent-magnet machine." IEEE Transactions on Industrial Electronics 58.7 (2011): 2818-2825.

[7] A. Al-Timimy et al., "Design and optimization of a high power density machine for flooded industrial pump," 2016 XXII International Conference on Electrical Machines (ICEM), Lausanne, 2016, pp. 1480-1486.

[8] A. Al-Timimy et al., "Trade-off analysis and design of a high power density PM machine for flooded industrial pump," IECON 2016 - 42nd Annual Conference of the IEEE Industrial Electronics Society, Florence, Italy, 2016, pp. 1749-1754.

[9] Z. Xu et al., "Thermal management of a permanent magnet motor for an directly coupled pump," 2016 XXII International Conference on Electrical Machines (ICEM), Lausanne, 2016, pp. 2738-2744.

[10] J.T. Chen, and Z.Q Zhu. "Coil connections and winding factors in fluxswitching PM brushless AC machines." COMPEL-The international journal for computation and mathematics in electrical and electronic engineering 30.1 (2011): 84-97.

[11] J.T. Chen, Z.Q. Zhu, A.S. Thomas and D. Howe, "Optimal combination of stator and rotor pole numbers in flux-switching PM brushless AC machines," ICEMS 2008. Wuhan, 2008, pp. 2905-2910.

[12] Y. Li, S. Li, Y. Yang and B. Sarlioglu, "Analysis of flux switching permanent magnet machine design for high-speed applications," IEEE ECCE 2014, Pittsburgh, PA, 2014, pp. 302-309.

[13] J.T. Chen, Z.Q. Zhu, S. Iwasaki and R.P. Deodhar, "Influence of Slot Opening on Optimal Stator and Rotor Pole Combination and Electromagnetic Performance of Switched-Flux PM Brushless AC 
Machines," in IEEE Transactions on Industry Applications, vol. 47, no. 4, pp. 1681-1691, July-Aug. 2011.

[14] Zhu, Z. Q., et al. "Influence of design parameters on output torque of flux-switching permanent magnet machines." 2008 IEEE Vehicle Power and Propulsion Conference. IEEE, 2008.

[15] A. Thomas, Z.Q. Zhu, G.W. Jewell and D. Howe, "Flux-Switching PM Brushless Machines with Alternative Stator and Rotor Pole Combinations" 2008 International Conference on Electrical Machines and Systems (ICEMS 2008).

[16] K. Kyohei, T. Kakishima, and A. Chiba. "Estimation and comparison of the windage loss of a $60 \mathrm{~kW}$ Switched Reluctance Motor for hybrid electric vehicles." 2014 International Power Electronics Conference (IPEC-Hiroshima 2014-ECCE ASIA).

\section{BIOGRAPHIES}

Ahmed Al-Timimy received his M.Sc. degree in Electrical Engineering from the University of Technology, Baghdad, Iraq in 2012. He is currently working towards his $\mathrm{PhD}$ in electro-magnetic and electrical machine design with Power Electronics, Machines and Control Group at the University of Nottingham. His main research interests are design and analysis of high performance electrical machines for aerospace applications.

Paolo Giangrande received his $\mathrm{Ph} . \mathrm{D}$. degree in electrical engineering from the Technical University of Bari, Bari, Italy, in 2011. In 2008, he was a Marie Curie Intra-European Fellow at the University of Malta, Tal-Qroqq, Malta. Since January 2012, he has been a Research Associate with the PEMC Group, The University of Nottingham, Nottingham, U.K. His research interests include sensorless control of ac electric drives and intelligent motion control, as well as design, modeling, and parameter identification of electrical machines for aerospace applications.

Michele Degano (M'15) received the Laurea degree in Electrical Engineering from the University of Trieste, Italy, in 2011 and the Ph.D. degree in Industrial Engineering from the University of Padova, Italy, in 2015. During his doctoral training, he has cooperated with several local companies for the design and permanent magnet machines. In 2015 he joined the Power Electronics, Machines and Control Research (PEMC) Group, University of Nottingham, U.K, as a Research Fellow. His main research interests are in the design and optimization of permanent magnet machines, reluctance and permanent-magnet-assisted synchronous reluctance motors through genetic optimization techniques, in applications ranging from small to large power. He is currently an assistant professor teaching advanced electrical machines at the University of Nottingham.

Michael Galea received his $\mathrm{PhD}$ in electrical machines design from the University of Nottingham, UK, where he has also worked as a Research Fellow. He is currently a Lecturer in Electrical Machines and Drives within the PEMC research group of the University of Nottingham. He is the Deputy Director of the Institute for Aerospace Technology at the University of Nottingham, where he is also a Lecturer in Aerospace Systems Integration and where he manages a number of diverse projects related to the more / all electric aircraft and associated fields. His main research interests are design, analysis and thermal management of electrical machines and drives and the more electric aircraft.

Chris Gerada (M'05) received the Ph.D. degree in numerical modeling of electrical machines from The University of Nottingham, Nottingham, U.K., in 2005. He subsequently worked as a Researcher with The University of Nottingham on high performance electrical drives and on the design and modeling of electromagnetic actuators for aerospace applications. Since 2006, he has been the Project Manager of the GE Aviation Strategic Partnership. He became a Lecturer in electrical machines in 2008, an Associate Professor in 2011, and a Professor in 2013 at The University of Nottingham. His main research interests include the design and modeling of high-performance electric drives and machines. Prof. Gerada serves as an Associate Editor for the IEEE TRANSACTIONS ON INDUSTRY APPLICATIONS and is the Chair of the Electrical Machines Committee of the IEEE Industrial Electronics Society. 